\title{
Seropositivity to Leptospira interrogans serovar Bratislava associated to reproductive problems without significant biochemical or hematological alterations in horses
}

\author{
Soropositividade para Leptospira interrogans serovar Bratislava associada a falhas reprodutivas \\ sem alterações hematológicas e bioquímicas significativas em cavalos
}

Melissa Pinna $^{\mathrm{I}}$ Gabriel Martins $^{\mathrm{I}}$ Isabel Freire $^{\mathrm{I}}$ Walter Lilenbaum ${ }^{\mathrm{I}}$

- NOTE -

\begin{abstract}
The objective was to study haematological and biochemical alterations associated to seropositivity to Leptospira interrogans serovar Bratislava infection in horses with reproductive alterations, such as neonatal deaths, embryonic deaths and abortions. A flock of mares with poor reproductive performance was studied. Eighty-two (58.6\%) were seropositive (titre 200); 72 of those (87.8\%) for Bratislava. Slight haematological and biochemical alterations were observed, being more frequent $(P<0.05)$ in horses seropositive versus seronegative. In conclusion horses seropositive for Bratislava had no consistent, severe alteration in values for hematology and biochemistry serum. Those findings reinforce this serovar as adapted to the horse and causing only mild symptoms, focused on reproductive problems.
\end{abstract}

Key words: leptospirosis, horse, Bratislava, hematology, biochemistry.

\section{RESUMO}

O objetivo deste trabalho foi estudar alterações hematológicas e bioquímicas associadas à soropositividade para Leptospira interrogans sorovar Bratislava em cavalos com alterações reprodutivas, tais como mortes neonatais, absorção embrionária e abortamentos. Um rebanho de éguas com baixos índices reprodutivos foi estudado. Oitenta e duas $(58,6 \%)$ foram soropositivas (títulos 200), sendo 72 destas $(87,8 \%)$ para Bratislava. Foram observadas poucas alterações hematológicas e bioquímicas, mais frequentes $(P<0,05) \mathrm{em}$ éguas soropositivas do que soronegativas. Cavalos soropositivos para Bratislava não tinham alterações graves nos valores hematológicos e bioquímicos. Esses achados reforçam que esse sorovar seja adaptado de cavalos e cause apenas sintomas brandos, associados a falhas reprodutivas.

Palavras-chave: leptospirose, cavalos, Bratislava, hematologia, bioquímica.
Leptospirosis is an important infectious disease in horses, characterized mainly by reproductive problems (ELLIS et al., 1983b; LILENBAUM, 1998; FAINE et al., 2000; LÉON et al., 2006). While still controversy, serovar Bratislava was regarded as adapted to horses, involved in primarily reproductive problems with only mild systemic effects and important economic hazards (ELLIS et al., 1983a; ELLIS et al., 1983b; PINNA et al., 2007).

There is a lack of studies regarding hematological and biochemical changes in horses infected with leptospirosis, what can be useful to a better understanding of the systemic effects of the infection. BRYANS (1955) studied horses experimentally infected with the incidental (non-adapted) serovar Pomona and detected leucocytosis, neutrophilia, eosinopenia, and lymphopenia, in addition to high serum bilirubin concentrations and albuminuria. However, there are apparently no reports regarding hematological or biochemical alterations in horses infected with the adapted serovar Bratislava. Therefore, the primary objective was to study systemic and reproductive alterations in horses seropositive and seronegative to Leptospira interrogans serovar Bratislava through the analysis of haematological and biochemical patterns.

A flock of 140 Campolina mares, with a recent history of poor reproductive performance (including abortions), was studied. Adetailed physical examination was conducted, and for each horse, blood samples were

'Laboratório de Bacteriologia Veterinária, Instituto Biomédico, Universidade Federal Fluminense (UFF), Rua Hernani Mello, 101/ 309, 24210-130, Niterói, RJ, Brasil. E-mail: mipwalt@ vm.uff.br.* Autor para correspondência. 
collected from the jugular. Collection of the samples occurred during the abortion outbreak. After collected, blood samples were chilled, immediately transported to the laboratory and analyzed for serology, hematology and biochemical tests, which were conducted in the same day of collection. Comprehensive assessment of hematology was conducted, including haemoglobin concentration, hematocrit, red blood cell (RBC) count, mean corpuscular volume (MCV), mean corpuscular hemoglobin $(\mathrm{MCH})$, mean corpuscular hemoglobin concentration (MCHC), red cell distribution width (RDW), white blood cell (WBC) count, white blood cell differential count, platelet count, and determination of plasma proteins by electrophoresis and fibrinogen determination (Schalm method). An automatic cell counter Coulter T 890 (Beckman Inc., Fullerton, Calif., USA) was used.

Biochemistry serum included alanine aminotransferase (ALT), aspartate aminotransferase (AST), gamma-glutamyl transferase (GGT), alkaline phosphatase (ALP), total, direct and indirect bilirubin (TB, DB, and IB, respectively), blood urea nitrogen (BUN), creatinine, creatine phosphokinase (CPK), and lactate dehydrogenase (LDH). All biochemical analyses were conducted with an automated serum analyser (Ciba Express 550, Ciba Corning Inc., Indiana, USA) using commercial kits (Biotecnica ${ }^{\circledR}$, Varginha, MG, Brazil), in accordance with the manufacturer's instructions.

Serum samples were tested for specific antiLeptospira antibodies by the microscopic agglutination test (MAT) for 21 serovars of Leptospira sp. representing 16 serogroups. Titres $\geq 200$ were considered reactive and the antigen that gave the highest titre was considered to be the infective serovar (FAINE et al., 2000).

Due to the substantial variation in physiologic values reported in the literature, reference values were established based on seronegative horses. In that regard, for each end point, confidence intervals $(\alpha=0.05)$ were calculated for seronegative horses, and the proportion of seropositive horses with values that were below, within, or above the range of the confidence interval was determined. A Student's $t$-test was used to compare values between seropositive and seronegative horses.

No abnormalities were detected during the physical examination and body condition score of the horses ranged from 6 to 7. There was a history of reproductive problems on the studied flock, and 42 (30\%) mares presented reproductive failure, characterized by 11 neonatal death ( $7.8 \%$ of the flock), 14 embryonic deaths (on days 15 to 35 of pregnancy)
(10\%), and 17 abortions (12.1\%). Those problems were more common in seropositive than seronegative mares (48.6 vs $12.1 \%$; $\mathrm{P}<0.05$ ).Among the 140 mares sampled $72(58.6 \%)$ were reactive to Bratislava with $51.4 \%$ of them having high titres ( $\geq 800)$, what strongly suggest the presence of leptospirosis on the studied flock. Samples were divided into two groups: 58 horses seronegative and 72 seropositive to Bratislava. Samples from the 10 horses that were reactive to other serovars were excluded from the study.

In relation to hematological findings, WBC count and WBC differential count (neutrophils and lymphocytes), all significantly exceeded reference values, whereas MCHC was significantly decreased (Table 1). In relation to biochemical findings, creatinine, ALP, ALT and total and direct bilirubin (TB and DB) exceeded reference values.

In spite of being considered as adapted to horses and causing reproductive disorders in this species (ELLIS et al., 1983a; LÉON et al., 2006), Bratislava infection in horses has not often been reported and is apparently frequently misdiagnosed (ELLIS et al., 1983b; PINNA et al., 2007). In the studied flock, seropositivity seemed to be much higher than that commonly reported, even when flocks in the same region and with a history of reproductive problems were investigated (LILENBAUM, 1998). Although this serovar has never been isolated in Brazil, the presence of seropositive flocks to Bratislava has been reported (PINNA et al., 2007). Unfortunately, samples of abortions or placentas could not be obtained and processed for either culture or molecular diagnosis. Nevertheless, based on the serological findings and mainly due to the high titres that were observed, it was suggested that Bratislava exposure was associated to the reproductive problems that were observed in the studied flock. Titres $\geq 100$ at MAT are considered in many countries as sufficient to establish a diagnosis of leptospirosis in horses (ELLIS et al., 1983b; BERNARD et al., 1993), but, since the study was conducted in an endemic region, a higher cut-off point was adopted, in order to avoid cross-reactivity (LILENBAUM, 1998). It's important to note that the introduction of specific antimicrobial treatment (dihydrostreptomycin) and the imposition of corrective measures regarding the leptospirosis control were efficient to reduce the reproductive problems (data not shown).

In relation to the hematologic and biochemical changes in seropositive horses, it was remarkable that only few parameters were altered. A slight increase in WBC count due to neutrophilia suggests the presence of a bacterial infectious disease, 
Table 1 - Confidence intervals (derived from 58 seronegative horses) for hematological and biochemical values, and results (in relation to CI) from 72 horses seropositive to Leptospira interrogans serovar Bratislava.

\begin{tabular}{|c|c|c|c|c|c|}
\hline \multirow{2}{*}{ Samples } & \multirow{2}{*}{$\begin{array}{c}\text { Seronegative } \\
\text { Confidence Interval (CI) }\end{array}$} & \multicolumn{4}{|c|}{ - } \\
\hline & & Average & $<\mathrm{CI}$ & $=\mathrm{CI}$ & $>\mathrm{CI}$ \\
\hline \multicolumn{6}{|l|}{ Hematology } \\
\hline $\mathrm{RBC}$ count & $7,148-7,981$ & 7,340 & 40.0 & 31.4 & 28.6 \\
\hline Hemoglobin & $10.8-11.9$ & 10.9 & 51.4 & 11.4 & 37.2 \\
\hline Hematocrit & $31.5-35.1$ & 31.7 & 42.9 & 31.4 & 25.7 \\
\hline $\mathrm{MCV}$ & $42.9-45.4$ & 43.1 & 42.9 & 28.6 & 28.5 \\
\hline $\mathrm{MCHC}$ & $33.8-34.6$ & $33.4 *$ & 65.7 & 11.4 & 22.9 \\
\hline Platelet & $240-409$ & 388 & 42.9 & 20.0 & 37.1 \\
\hline Plasma ptns & $7.31-7.83$ & 7.43 & 37.1 & 45.7 & 17.2 \\
\hline Fibrinogen & $281-422$ & 308 & 34.3 & 57.1 & 8.6 \\
\hline WBC count & $10,856-12,957$ & $13,977^{*}$ & 28.6 & 14.3 & 57.1 \\
\hline Basophils & $28.7-96.6$ & 42.5 & 82.9 & 2.9 & 14.2 \\
\hline Eosinophils & $519-893$ & 558 & 57.1 & 25.7 & 17.2 \\
\hline Neutrophils & $4,359-5,435$ & $5,918^{*}$ & 34.3 & 20.0 & 45.7 \\
\hline Lymphocytes & $5,058-6,946$ & $7,215^{*}$ & 25.7 & 11.4 & 62.9 \\
\hline Monocytes & $140-280$ & 237 & 37.1 & 31.4 & 31.5 \\
\hline \multicolumn{6}{|l|}{ Biochemistry } \\
\hline ALT & $11.0-15.2$ & $17.5^{*}$ & 14.3 & 31.4 & 54.3 \\
\hline AST & $303-336$ & 317 & 42.9 & 22.9 & 34.2 \\
\hline GGT & $15.0-19.8$ & 18.3 & 28.6 & 34.3 & 37.1 \\
\hline ALP & $245-321$ & $350 *$ & 22.9 & 25.7 & 51.4 \\
\hline $\mathrm{TB}$ & $0.65-0.93$ & $1.06^{*}$ & 25.7 & 20.0 & 54.3 \\
\hline DB & $0.22-0.35$ & $0.40^{*}$ & 34.3 & 14.3 & 51.4 \\
\hline IB & $0.37-0.64$ & 0.63 & 37.1 & 28.6 & 34.3 \\
\hline BUN & $33-41$ & 39 & 17.1 & 40.0 & 42.9 \\
\hline CREATININ & $0.67-1.1$ & $1.2^{*}$ & 28.6 & 11.4 & 60.0 \\
\hline CPK & $343-444$ & 373 & 54.3 & 20.0 & 25.7 \\
\hline LDH & $629-770$ & 763 & 20.0 & 34.3 & 45.7 \\
\hline
\end{tabular}

* Difference $(\mathrm{P}<0.05)$

whereas the mild increases in creatinin, ALP, ALT and bilirubins may suggest some hepatic damage. Fibrinogen rate, a valuable tool for evidencing acute infection in horses, was not altered. Those findings strongly contrasted to the severe alterations that are reported to infections in many species, including horses, determined by incidental serovars, particularly Icterohaemorrhagiae (FAINE et al., 2000). Those findings reinforce Bratislava as a serovar adapted to horse that causes only mild symptoms, focused on reproductive problems.

In conclusion, even in the presence of reproductive problems and seroreactivity to leptospirosis, horses seropositive for Bratislava had no consistent or severe alteration for hematology and serum biochemistry values, what reinforces this serovar as adapted to the horse, which causes primarily reproductive disease, with no systemic effects.

\section{ACKNOWLEDGEMENTS}

The authors are grateful for the assistance received from Dr. John Kastelic, Dr. Alessandra Crosara, Prof. Nadia Almosny and CAD. The study was supported by Coordenação de Aperfeiçoamento de Pessoal de Nível Superior, Conselho Nacional de Desenvolvimento Científico e Tecnológico (CNPq), and Fundação de Amparo à Pesquisa do Estado do Rio de Janeiro. WL is a CNPq fellow.

\section{REFERENCES}

BERNARD, W. et al. Leptospiral abortion and leptospiruria in horses from the same farm. Journal of the American Veterinary Medical Association, v.202, p.1285-1286, 1993.

BRYANS, J. Studies on equine leptospirosis. Cornell Veterinarian, v.45, p.16-50, 1955.

ELLIS, W. et al. Leptospiral infection in aborted equine foetuses. Equine Veterinary Journal, v.15, p.321-324, 1983a. 
ELLIS, W. et al. Leptospiral infection in horses in Northern Ireland: Serological and microbiological findings. Equine Veterinary Journal, v.15, p.317-320, 1983b.

FAINE, S. et al. Leptospira and Leptospirosis. Australia: Med Sci, 2000. 296p.

LÉON, A. et al. Identification of pathogenic Leptospira strains in tissues of a premature foal by use of polymerase chain reaction analysis. Journal of Veterinary Diagnostic Investigation, v.18, p.218-221, 2006. Available from: <http://jvdi.org/ content/vol18/issue2/index.dtl>. Accessed: Jul. 28, 2010. doi: 10.1186/1751-0147-51-15.
LILENBAUM, W. Leptospirosis on animal reproduction: IV. Serological findings in mares from six farms in Rio de Janeiro, Brazil (1993-1998). Brazilian Journal of Veterinary Research and Animal Science, v.35, p.61-63, 1998. Available from: <http:// www.scielo.br/scielo.php? script $=$ sci_serial\&pid $=1413$ 9596\&lng=en\&nrm=iso>. Accessed: Jul. 28, 2010. doi: 10.1590/ S1413-95961998000200002.

PINNA, M. et al. Outbreak of equine leptospirosis by s. Bratislava. Online Journal of Veterinary Research, v.11, p.1-4, 2007. 